\title{
Uterine Artery Ligation in the Maternal Rat Alters Fetal Tissue Glucose Utilization
}

\author{
FREDERICK L. LUEDER AND EDWARD S. OGATA \\ Departments of Pediatrics and Obstetrics and Gynecology, Northwestern University Medical School, Division of \\ Neonatology, Children's Memorial and Prentice Women's Hospitals, Chicago, Illinois 60614 and Evanston
} Hospital, Evanston, Illinois 60201

\begin{abstract}
We studied the effects of maternal uterine artery ligation on fetal rat tissue glucose utilization (GU). Unilateral uterine artery ligations were performed on the 19 th $\mathrm{d}$ of gestation (term $21.5 \mathrm{~d}$ ) and $2-\left[{ }^{3} \mathrm{H}\right]$ deoxy-D-glucose was used to measure GU of placenta, liver, brain, muscle, kidney, and heart from fetuses in the ligated (IUGR) and nonligated (control) uterine horns 24 and $48 \mathrm{~h}$ after the procedure. At both periods, IUGR fetuses weighed significantly less and had lower fetal/maternal plasma glucose ratios than controls. Twenty-four $h$ after ligation, placenta, liver, brain, and muscle from IUGR fetuses had lower relative $\mathrm{GU}$ rates than corresponding tissues from control fetuses $(p<0.01-0.05)$. However, at $48 \mathrm{~h}$, IUGR liver, muscle, kidney, and heart had higher relative $\mathrm{GU}$ rates than control tissues $(p<0.01-0.05)$. The lower GU of IUGR fetal tissues observed at $\mathbf{2 4} \mathrm{h}$ postligation was likely related to the acute decrease in fetal glucose availability. Other factors, such as hypoxemia and acidosis, that affect cellular metabolism may also have led to lower GU rates. The increase in GU by IUGR tissues at $48 \mathrm{~h}$ occurred despite a persistence of low fetal glucose concentrations and can be explained by either: 1) an attempt by IUGR fetal tissues to compensate for the persistently low plasma glucose; 2) an increased demand for metabolic fuel for repair processes; or 3 ) a less efficient use of glucose due to alterations in cellular respiration. We speculate that this increase in fetal tissue GU may be partially responsible for the supranormal glucose requirements seen in smallfor-gestational-age newborns. (Pediatr Res 28: 464-468, 1990)
\end{abstract}

\section{Abbreviations}

GU, glucose utilization

IUGR, intrauterine growth retardation

LC, lumped constant

$P_{k}$, placental discrimination constant

2DG, 2-deoxyglucose

2DG6P, 2-deoxyglucose-6-phosphate

Maternal hypertension, chronic renovascular diseases, and several other conditions are associated with reduced uterine blood flow during pregnancy. These conditions are associated with a high incidence of IUGR and increased fetal and neonatal mortality $(1,2)$. In addition, growth-retarded neonates are at significant risk for neonatal hypoglycemia (3). The mechanisms

Received December 27, 1989; accepted June 13, 1990.

Correspondence: Frederick L. Lueder, M.D., Department of Pediatrics, Evanston Hospital, 2650 Ridge Road, Evanston, IL 60201.

Supported in part by NIH Grant IPO119070 and the Juvenile Diabetes Foundation. by which these conditions retard fetal growth and the processes that are responsible for the neonatal hypoglycemia are not completely understood.

Maternal uterine artery ligation has frequently been used to study the consequences of reduced uterine blood flow on the fetus. This procedure severely retards fetal growth in the rat (410). Previous studies using this model have suggested that limited fetal nutrient availability and altered placental gaseous exchange play important roles in the impairment of fetal growth $(5,6)$. Restricted glucose delivery to the developing fetus leads to low levels of glucose, the primary fetal metabolic substrate, and insulin, an important fetal growth hormone (6). Uterine artery ligation has been shown to produce fetal hypoxia, hypercapnia, and acidosis (6), which likely affect both cellular metabolism and fetal growth. This model is also associated with reduced glycogen stores and delayed induction of gluconeogenic enzymes $(7,8)$. These processes also appear to be important factors in the development of hypoglycemia in the small-for-gestational-age newborn $(11,12)$. However, small-for-gestational-age human infants may have increased metabolic rates $(13,14)$ and rapid clearance of i.v. administered glucose $(15,16)$, which could also contribute to the development of hypoglycemia.

The effects of uterine artery ligation on fetal GU remain unknown. Knowledge of these effects may further define the mechanisms responsible for altered fetal glucose homeostasis, IUGR, and neonatal hypoglycemia. Studies of fetal GU, however, would be incomplete if individual tissue responses to uterine artery ligation were not considered. Fetal brain growth is minimally, if at all, affected by this procedure, whereas hepatic growth is markedly impaired $(4,5)$. Therefore, the effects on GU of individual tissues may differ. Furthermore, these effects may change with time after the procedure. We therefore performed unilateral uterine artery ligations on pregnant rats and measured GU of several major fetal tissues from fetuses in the ligated and nonligated uterine horns at 24 and $48 \mathrm{~h}$ after ligation.

\section{MATERIALS AND METHODS}

We used a modification of Sokoloff's 2DG method to measure fetal rat tissue GU (17-19). 2DG is transported into the cell and phosphorylated by hexokinase or glucokinase in a manner similar to glucose. Because of the absence of the hydroxyl group at position 2, the phosphorylated product, 2DG6P, is not further metabolized (17). The accumulation of 2DG6P within a tissue can therefore be used to determine GU. The standard equation to measure $\mathrm{GU}$ of a particular tissue after an i.v. pulse of $2 \mathrm{DG}$ is:

$$
\mathrm{GU}=\frac{[2 \mathrm{DG} 6 \mathrm{P}] \mathrm{T}}{\mathrm{LC} \int_{0}^{\mathrm{T}} \frac{[2 \mathrm{DG}] \mathrm{t}}{[\text { glucose }]} d t}
$$

where $[2 \mathrm{DG} 6 \mathrm{P}]$ is the tissue concentration of $2 \mathrm{DG} 6 \mathrm{P}$ at time $\mathrm{T}$, 
[2DG] and [glucose] are the plasma concentrations of $2 \mathrm{DG}$ and glucose, and LC is the lumped constant (20).

$\mathrm{LC}$ is a correction factor that accounts for differences of affinities and maximal velocities of transport and phosphorylation between 2DG and glucose. Each tissue has a specific LC; however, due to technical limitations, the LC of individual fetal rat tissues cannot be determined. The above equation without this correction factor provides a measure of relative GU. In our study, we compared relative GU rates of similar tissues from experimental and control fetuses on the assumption that the experimental procedure had not affected the LC.

Measurements of fetal tissue $\mathrm{GU}$ require knowledge of the fetal plasma concentrations of 2DG and glucose. However, one cannot sample fetal blood in the unanesthetized rat and, as anesthesia may alter glucose metabolism, measurements of GU must be made in the awake animal. Using the method of Leturque et al. $(18,19)$, we established the relationship between fetal and maternal plasma concentrations of 2DG and glucose after a pulse of 2DG for each of the study and control groups of fetuses in anesthetized rats. This relationship is best expressed as a ratio, which has been termed $\mathrm{P}_{\mathrm{k}}$ :

$$
P_{k}=\frac{\int_{0}^{T} \frac{[2 D G] t}{[\text { glucose }]} d t \text { (fetal plasma) }}{\int_{0}^{T} \frac{[2 \mathrm{DG}] \mathrm{t}}{[\text { glucose }]} d t \text { (maternal plasma) }}
$$

Once $P_{k}$ is known, relative $G U$ rates of fetal tissues can be measured in the awake animal using maternal arterial plasma concentrations of $2 \mathrm{DG}$ and glucose and the fetal tissue concentrations of 2DG6P:

$$
\text { Relative } \mathrm{GU}=\frac{[2 \mathrm{DG} 6 \mathrm{P}] \mathrm{T} \text { (fetal tissue) }}{\mathrm{P}_{\mathrm{k}} \int_{0}^{\mathrm{T}} \frac{[2 \mathrm{DG}] \mathrm{t}}{\text { [glucose }]} \mathrm{dt} \text { (maternal plasma) }}
$$

Surgical procedure. Nine-wk-old pregnant Sprague-Dawley rats were obtained from Harlan Laboratories (Madison, WI), housed separately, and allowed free access to water and food. On d 19 of gestation (term 21.5 d), we anesthetized each maternal rat with intraperitoneal injections of $6 \mathrm{mg} / \mathrm{kg}$ xylazine and 30 $\mathrm{mg} / \mathrm{kg}$ ketamine and made a vertical abdominal incision under sterile conditions.

For GU measurements, the left cervical uterine artery was ligated with a single silk suture. The right uterine horn was similarly manipulated but the artery was not ligated. The left jugular vein and carotid artery were then catheterized with sterile polyvinyl tubing. Rats were excluded from the GU studies if they had fewer than four or greater than seven fetuses per uterine horn or a discrepancy of more than two fetuses between uterine horns.

For $\mathrm{P}_{\mathrm{k}}$ determinations, bilateral uterine artery ligations or sham surgeries were performed because eight or more fetal blood samples were required. Catheterizations were done as in the GU studies. All animals were allowed to recover for $24 \mathrm{~h}$ before further testing.

This protocol was approved by the Animal Care Committees of Northwestern University and Children's Memorial Hospital.

$G U$. Relative GU rates of fetal tissues were measured at 24 and $48 \mathrm{~h}$ after ligation of the uterine artery. After a 3- to 5-h fast, each rat was placed in a snug but not overly tight restraint. Once the rat was tranquil, $370 \mathrm{kBq}$ (sp act $262.7 \mathrm{kBq} / \mathrm{nmol}$ ) of $\left[{ }^{3} \mathrm{H}\right]$ 2DG (New England Nuclear, Boston, MA) was injected through the jugular catheter. Maternal blood $(100 \mu \mathrm{L})$ was obtained through the arterial catheter at $1,3,5,10,15,20,25,30,35$, and $43 \mathrm{~min}$ after the injection. At $44 \mathrm{~min}$, the mother was anesthetized with $40 \mathrm{mg} / \mathrm{kg}$ i.v. pentobarbital and her abdominal wound was reopened. At $45 \mathrm{~min}$, three fetuses from the mid-portion of each uterine horn were removed, decapitated, frozen in their entirety in liquid nitrogen, and weighed. All six fetuses were removed and frozen within $2 \mathrm{~min}$. Approximately $100-\mathrm{mg}$ portions of the placenta (villous chorion) and liver, and the entire heart, cerebral hemispheres, kidney, and hind limb muscles were removed from each frozen fetus and weighed. Tissues were placed in $0.5 \mathrm{~mL} 1 \mathrm{~N} \mathrm{NaOH}$, heated to $60^{\circ} \mathrm{C}$ until completely digested, and then neutralized with $0.5 \mathrm{~mL} 1 \mathrm{~N} \mathrm{HCl} \mathrm{(21).} \mathrm{Tissue} \mathrm{homog-}$ enates were later assayed for $\left[{ }^{3} \mathrm{H}\right] 2 \mathrm{DG} 6 \mathrm{P}$ activity.

$P_{k} . \mathrm{P}_{\mathrm{k}}$ were also determined 24 and $48 \mathrm{~h}$ after bilateral uterine artery ligations or sham surgery. We anesthetized the maternal rat with $40 \mathrm{mg} / \mathrm{kg}$ i.v. pentobarbital, performed a tracheostomy, and ventilated the rat in a fractional inspired oxygen of 0.21 at 80 breaths/min with a tidal volume of $1.7 \mathrm{~mL}$. The abdominal wound was then reopened and covered with warm saline-soaked gauze. Care was taken not to manipulate the uterine horns in a way that would interfere with uterine blood flow. Body temperature was maintained with the use of a heating pad. At time 0 , we injected $370 \mathrm{kBq}$ of $\left[{ }^{3} \mathrm{H}\right] 2 \mathrm{DG}$ into the jugular catheter. Maternal blood was collected at the same times as in the GU studies. Immediately after obtaining each maternal sample, a small hysterotomy was made and a single fetus was exposed leaving the uteroplacental-fetal circulation intact (22). The fetal axillary artery was severed and blood was collected in heparinized capillary tubes. Fetal blood was usually obtained at $2,4,6,11$, $16,21,26,31,36$, and $44 \mathrm{~min}$ after the 2DG injection.

Analyses. Plasma $\left.{ }^{3} \mathrm{H}\right] 2 \mathrm{DG}$ activity. Maternal blood (from GU measurements and $\mathrm{P}_{k}$ determinations) and fetal blood (from $\mathrm{P}_{k}$ determinations) were centrifuged at $9000 \times g$. Fifty $\mu \mathrm{L}$ of plasma from each sample were added to $5 \mathrm{~mL}$ of scintillation cocktail (Cytoscint, ICN, Cleveland, $\mathrm{OH}$ ) and counted for $10 \mathrm{~min}$. The plasma glucose concentration of each sample was determined in duplicate (Beckman Glucose Analyzer II).

Tissue $\left[{ }^{3} H\right] 2 D G 6 P$ activity. To separate tissue $2 \mathrm{DG}$ from 2DG6P, we used a method based on the principle that although both 2DG and 2DG6P are soluble in $5 \% \mathrm{HClO}_{4}$, only 2DG remains soluble in a $\mathrm{Ba}(\mathrm{OH})_{2} / \mathrm{ZnSO}_{4}$ mixture (23). One $400-\mu \mathrm{L}$ aliquot of tissue homogenate was added to $1.0 \mathrm{~mL}$ of $5 \% \mathrm{HClO}_{4}$ and a second $400-\mu \mathrm{L}$ aliquot was added to $0.5 \mathrm{~mL} \mathrm{Ba}(\mathrm{OH})_{2}$ (Sigma Chemical Co., St. Louis, MO), followed by the addition of $0.5 \mathrm{~mL} \mathrm{ZnSO}_{4}$ (Sigma). After centrifugation, $700 \mu \mathrm{L}$ of each supernatant was added to $20 \mathrm{~mL}$ of scintillation cocktail and counted for $10 \mathrm{~min}$. The difference in radioactivity between the $\mathrm{HClO}_{4}$ - and $\mathrm{Ba}(\mathrm{OH})_{2} / \mathrm{ZnSO}_{4}$-treated samples was used as the tissue $\left[{ }^{3} \mathrm{H}\right] 2 \mathrm{DG} 6 \mathrm{P}$ activity.

Calculations. $P_{k}$ determinations. The ratio of $\left[{ }^{3} \mathrm{H}\right] 2 \mathrm{DG}$ activity to glucose concentration for each maternal and fetal plasma sample was plotted versus time (Fig. 1). The area under the maternal curve from time 0 to 45 min was obtained by establishing the best-fit curve using the double exponential equation: $\mathrm{y}=$ $\mathrm{Ae}^{\mathrm{Bx}}+\mathrm{Ce}^{\mathrm{Dx}}+\mathrm{E}$; where $\mathrm{A}, \mathrm{B}, \mathrm{C}, \mathrm{D}$, and $\mathrm{E}$ are constants chosen by a curve-fitting program. The integral of the equation was then calculated. Because the fetal plasma $\left[{ }^{3} \mathrm{H}\right] 2 \mathrm{DG}$ activity did not peak immediately after the $2 \mathrm{DG}$ injection, the area under the fetal curve from time 0 to the peak [2DG]/[glucose] value was determined separately. The area under the remaining fetal curve from the peak value to 45 min was calculated using the best-fit curve method. The ratio of the area under the fetal curve to the area under the maternal curve is equivalent to the $P_{k}$.

$G U$ measurements. The ratio of $\left[{ }^{3} \mathrm{H}\right] 2 \mathrm{DG}$ activity to glucose concentration for each maternal plasma sample was plotted versus time. The area under the curve from time 0 to $45 \mathrm{~min}$ was obtained, as before, using the best-fit curve method. The value of the integral was corrected by the previously determined $P_{k}$. The relative GU of a specific fetal tissue for a single experiment was calculated by dividing the average 2DG6P activity of that tissue from the three fetuses of either the ligated or nonligated uterine horn by the corrected value of the integral.

Statistical analysis. We used unpaired, one-tailed $t$ tests to determine differences between IUGR and control fetal weights. Group differences of $P_{k}$ values and fetal/maternal glucose ratios were determined by analysis of variance. Paired, two-tailed $t$ tests 


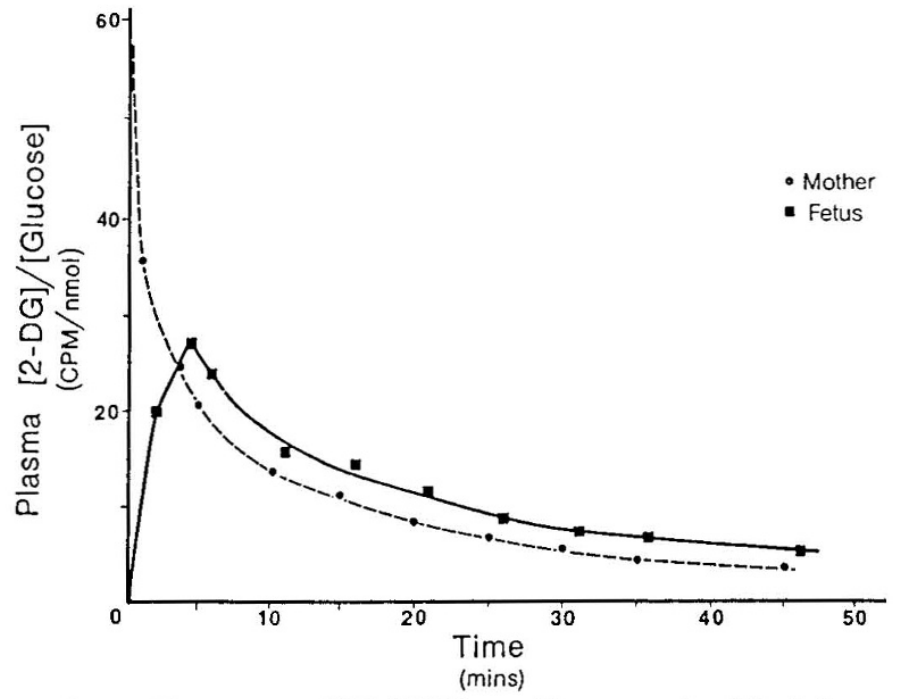

Fig. 1. Time course of $[2 \mathrm{DG}] /[$ Glucose $]$ in maternal and fetal plasma after a single maternal i.v. injection of $\left[{ }^{3} \mathrm{H}\right] 2$-deoxyglucose. Best-fit curves were generated using a double exponential equation. The ratio of the areas under the fetal and maternal curves were used as the $\mathrm{P}_{\mathrm{k}}$.

were used to analyze GU differences between IUGR and control fetal tissues. Data are presented as mean \pm SEM.

\section{RESULTS}

Fetal weight. At $24 \mathrm{~h}$ after uterine artery ligation, IUGR and control fetuses weighed $3.02 \pm 0.14$ and $3.37 \pm 0.13 \mathrm{~g}$, respectively $(p<0.05)$. At $48 \mathrm{~h}$, IUGR fetuses weighed $3.61 \pm 0.11 \mathrm{~g}$, whereas control fetuses weighed $4.70 \pm 0.08$ grams $(p<0.005)$.

$P_{k}$ and fetal maternal glucose. Uterine artery ligation resulted in significantly greater mean $P_{k}$ values at 24 and $48 \mathrm{~h}$ postligation (Table 1). Although maternal IUGR and control plasma glucose concentrations were similar, IUGR fetuses had significantly lower plasma glucose concentrations than controls at both periods, resulting in lower fetal/maternal glucose ratios. Uterine artery ligation was associated with reductions in the fetal/maternal glucose ratio of $19.2 \%$ at $24 \mathrm{~h}$ and $14.4 \%$ at $48 \mathrm{~h}$.

$G U$ studies. At $24 \mathrm{~h}$ postligation, placenta, liver, brain, and muscle from IUGR fetuses had lower relative GU rates than the respective tissues from control fetuses. Relative GU of kidney and heart were similar in IUGR and control fetuses (Fig. 2).

At 48 h, IUGR liver, muscle, kidney, and heart had higher relative GU rates than the control fetuses. Relative $\mathrm{GU}$ rates of placenta and brain did not differ between IUGR and control fetuses at this time (Fig. 3).

\section{DISCUSSION}

We found a biphasic response of fetal rat tissue GU after uterine artery ligation. At $24 \mathrm{~h}$ postligation, placenta, liver, cerebral hemispheres, and hind limb muscle from IUGR fetuses had lower relative $\mathrm{GU}$ rates than the corresponding tissues from control fetuses. However, at $48 \mathrm{~h}, \mathrm{GU}$ was higher in IUGR liver, hind limb muscle, kidney, and heart. All IUGR tissues demonstrated an increase in GU, relative to control, from 24 to $48 \mathrm{~h}$ postligation, with liver and muscle showing the greatest changes. IUGR tissues demonstrated an average decrease in GU of $8.2 \%$ at $24 \mathrm{~h}$ and an average increase of $22.2 \%$ at $48 \mathrm{~h}$ after uterine artery ligation.

Our results concur with two earlier studies. Nitzan and Groffman (9) found an increased uptake of ${ }^{14} \mathrm{C}$-glucose in vitro by IUGR liver slices but not by IUGR brain slices at term after uterine artery ligation in the rat. In a separate in vivo study, they found a relatively greater uptake of $2 D G$ by several IUGR rat fetal tissues $2 \mathrm{~d}$ after uterine artery ligation (5). However, because of their methodology, they could not quantitate fetal tissue GU. Our results are also supported by reports of increased glucose disappearance rates in hypoglycemic IUGR human newborns $(15,16)$. This observation has been considered to be the result of "growth-sparing" of metabolically active organs, e.g. brain and heart. Our data suggest that absolute increases in IUGR tissue GU may be partially responsible for these elevated glucose requirements.

We used a modification of the 2DG method described by Leturque et al. $(18,19)$ to measure relative GU rates of fetal rat tissue. In addition to the criteria described by Sokoloff et al. (17) for the original 2DG method, two further assumptions must be made: 1) glucose-6-phosphatase activity of fetal tissues is negligible or, if present, is similar between IUGR and control fetuses; and 2) the LC of fetal tissues is not affected by uterine artery ligation.

Glucose-6-phosphatase is only found in large concentrationin postnatal rat liver, kidney, and intestine (24). Although gl: cose-6-phosphatase is present in fetal rat liver and kidney, its activity remains low until birth (24-26). Small concentrations of this enzyme, however, may result in falsely low GU rates as calculated by the 2DG method (27). Our observation of higher GU of IUGR liver and kidney at $48 \mathrm{~h}$ postligation could have resulted from a delay in glucose-6-phosphatase induction not seen in controls. However, fetal hypoglycemia and hypoinsulinemia, as produced by maternal fasting or insulin infusion, increases glucose-6-phosphatase activity in fetal liver (28). Inasmuch as maternal uterine artery ligation also produces fetal hypoglycemia and hypoinsulinemia, IUGR fetal tissues would be expected to have higher enzyme activity than controls, thus resulting in lower rather than higher GU rates. Although the second assumption cannot be verified, it is doubtful that uterine artery ligation should have produced a change in the $\mathrm{Km}$ or $\mathrm{V}_{\max }$ of a tissue's transporter or hexokinase for 2DG without equally affecting that for glucose.

The $\mathrm{P}_{\mathrm{k}}$ accounts for differences in 2DG and glucose concentrations between maternal and fetal plasma after the administration of 2DG to the mother. The value of this ratio is influenced by at least three processes: 1) a lag period between the injection of $2 \mathrm{DG}$ into the maternal vein and its appearance in the fetal circulation (Fig. 1);2) a greater affinity of the glucose transporter for 2DG over glucose; and 3) a lesser affinity of placental hexokinase for 2DG. The first process will tend to decrease the value of $P_{k}$, whereas the second and third processes will tend to

Table 1. $P_{k}$ and fetal/maternal glucose ratios (mean $\pm S E M$ )

\begin{tabular}{ccccc}
\hline & $\mathrm{P}_{\mathrm{k}}$ & $\begin{array}{c}\text { Maternal glucose } \\
(\mathrm{mmol} / \mathrm{L})\end{array}$ & $\begin{array}{c}\text { Fetal glucose } \\
(\mathrm{mmol} / \mathrm{L})\end{array}$ & $\begin{array}{c}\text { Fetal/Maternal } \\
\text { glucose }\end{array}$ \\
\hline 24 h postligation & & & & \\
IUGR $(n=8)$ & $1.21 \pm 0.03^{*}$ & $5.6 \pm 0.2$ & $2.7 \pm 0.2^{*}$ & $0.49 \pm 0.02 \dagger$ \\
Control $(n=8)$ & $1.10 \pm 0.02^{*}$ & $5.3 \pm 0.2$ & $3.2 \pm 0.1^{*}$ & $0.61 \pm 0.01 \dagger$ \\
48 hostligation & & & & \\
IUGR $(n=7)$ & $0.95 \pm 0.03^{*}$ & $5.2 \pm 0.5$ & $3.6 \pm 0.3^{*}$ & $0.69 \pm 0.01 \dagger$ \\
Control $(n=7)$ & $0.93 \pm 0.01^{*}$ & $5.2 \pm 0.4$ & $4.2 \pm 0.3^{*}$ & $0.80 \pm 0.03 \dagger$ \\
\hline
\end{tabular}

$* p<0.05$ IUGR vs control.

$\dagger p<0.005$ IUGR $v s$ control. 


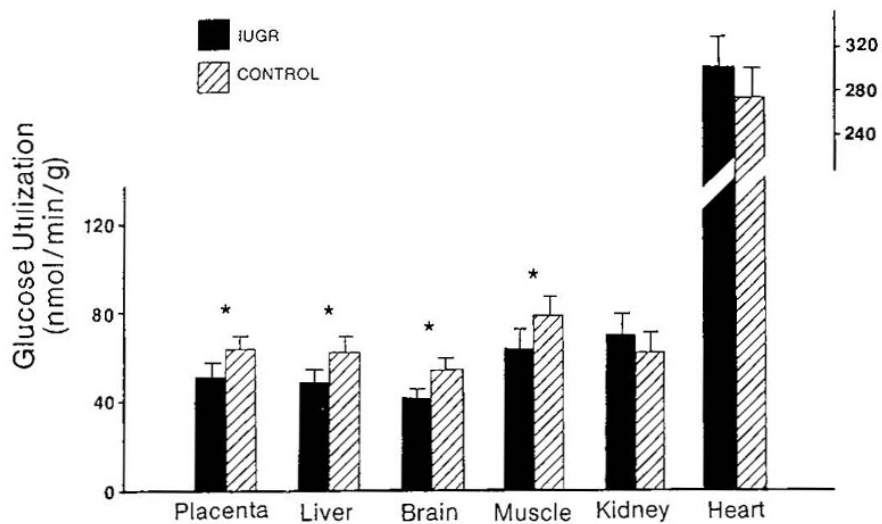

Fig. 2. Relative GU rates of fetal rat tissues $24 \mathrm{~h}$ after unilateral uterine artery ligation. ${ }^{*}$ indicates significant differences between IUGR and control fetal tissue $(p<0.05$ to $p<0.01), n=9$ experiments.

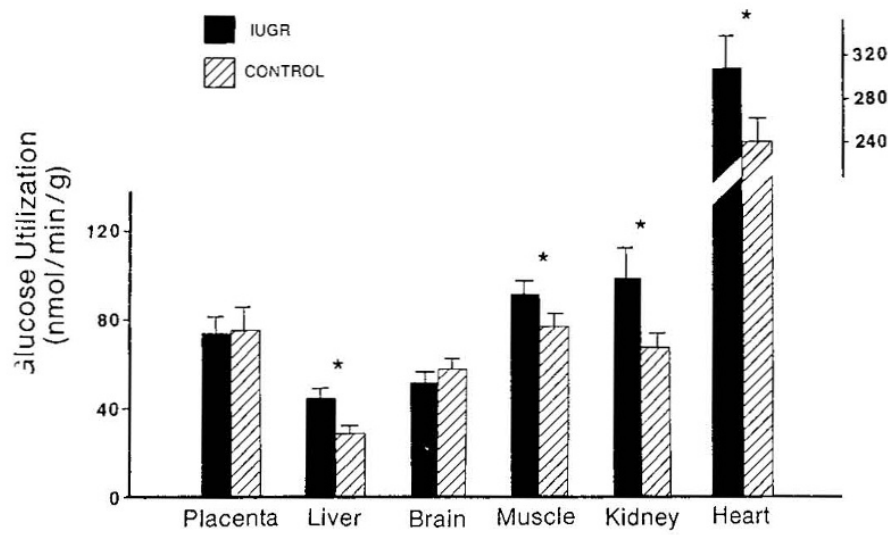

Fig. 3. Relative GU rates of fetal rat tissues $48 \mathrm{~h}$ after unilateral uterine artery ligation. * indicates $p<0.05$ to $p<0.01 . n=7$ experiments.

increase $P_{k}$. We found significantly higher $P_{k}$ values after uterine artery ligation. This finding may be explained by the production by the IUGR placenta of glucose transporters with relatively greater affinity for $2 \mathrm{DG}$ or hexokinases with relatively lower affinity for 2DG. Alternatively, with reduced uterine blood flow, a higher percentage of glucose and 2DG may have been extracted from the maternal circulation. This may have induced a change in the placental LC, thus explaining the higher $\mathrm{P}_{k}$ values in IUGR fetuses.

After 2DG administration to pregnant Wistar rats on d 19 of gestation, Leturque et al. (19) measured the ratio of the integrals of maternal to fetal blood 2DG/glucose, which is the inverse of our $\mathrm{P}_{\mathrm{k}}$. They obtained a value of $0.87 \pm 0.02$, the inverse of which (1.15) compares favorably with our $24 \mathrm{~h}$ control value. They also measured GU of placenta, liver, brain, muscle, and heart from d 19 fetuses during maternal hyperglycemic and euglycemic hyperinsulinemic clamp experiments $(19,20)$. They found $\mathrm{GU}$ rates of their control fetal tissues somewhat higher than those we observed for our respective control tissues. This difference may be due to the use of a different rat stain or use of a different $P_{k}$ value.

Several mechanisms may explain the differences in GU rates between IUGR and control tissues. The lower GU of IUGR tissues $24 \mathrm{~h}$ postligation is probably due to the acute decrease in fetal plasma glucose concentrations. Alterations in other factors that affect cellular metabolism such as hypoxia-induced reduction of cellular metabolism could also have affected GU.

The higher relative GU rates of IUGR tissues at $48 \mathrm{~h}$ postligation were not anticipated. They occurred despite a persistence of low fetal plasma glucose concentrations. In addition, we have previously documented low insulin levels in IUGR fetuses $48 \mathrm{~h}$ after uterine artery ligation (6). The mechanisms responsible for the paradoxical increase in uptake and phosphorylation of 2DG (and thus glucose) are not clear. This finding may reflect an adaptation or compensation by fetal tissues in response to persistently low glucose concentrations. By increasing the number of glucose transporters or the amount of hexokinase, fetal tissues would be more able to extract glucose from plasma. Other studies support this mechanism. Rat skeletal muscle cells up-regulate their 2DG uptake and have higher levels of glucose transporter mRNA when exposed to low (2 mM) glucose (29). Similarly, brains from chronically glucose-starved rats have elevated glucose transporter mRNA levels (30).

The higher GU may also be the result of an increased demand for metabolic fuel by IUGR tissues. Cellular death and structural damage are likely consequences of uterine artery ligation. Repair processes would require additional energy and thus could account for the elevated rates of GU. Alternatively, the increased demand for glucose may be explained by a decreased oxidation of carbons arising from glucose, which, in turn, is compensated for by increased glycolysis. Maternal uterine artery ligation significantly reduces the ATP/ADP ratio and profoundly alters cytosolic and mitochondrial redox states in fetal liver (31). These findings indicate a disruption of cellular respiration resulting in less ATP generated per unit glucose used. Because hexokinase, the rate-limiting enzyme of glycolysis, is inhibited by ATP and stimulated by ADP, this process could lead to increased GU by IUGR fetal tissues.

Additional factors may contribute to the relatively higher GU by IUGR fetal tissues. Collateral uterine circulation may be developing by $48 \mathrm{~h}$ after ligation. Although serial measurements of uterine/placental blood flow after uterine artery ligation are lacking, some investigators have found a persistence of reduced placental blood flow when expressed as $\mathrm{mL} / \mathrm{min}$ at 3 and $4 \mathrm{~d}$ postligation $(32,33)$. Higher fetal glucose concentrations and fetal/maternal glucose ratios were observed at $48 \mathrm{~h}$ postligation for both IUGR and control fetuses. Although the IUGR fetal/ maternal glucose ratio remained significantly lower than control, the increase in IUGR fetal glucose may reflect an improved availability of glucose that contributed to the higher GU rates of IUGR tissues. Although fetal insulin levels were not measured in our study, we have previously demonstrated low insulin concentrations in IUGR fetuses $48 \mathrm{~h}$ after ligation. This observation argues against the speculation of higher glucose availability and rules out the possibility of high insulin as a cause of the increased GU of IUGR tissues.

It should be noted that the GU of control liver decreases from d 20 to 21 (Figs. 2 and 3). This was not observed in IUGR liver and thus accounts for the relatively higher GU of IUGR liver at $48 \mathrm{~h}$ postligation. The cause of the lower GU of control liver at $48 \mathrm{~h}$ is not known but may reflect maturational processes such as completion of glycogen deposition.

IUGR neonates have been reported to have significantly increased energy requirements and are at risk of developing hypoglycemia compared with normally grown infants (3). The development of hypoglycemia results in part from limited hepatic glycogen stores and diminished gluconeogenic capability (11, 12). We speculate that a carryover of the increased tissue $\mathrm{GU}$ from fetal to neonatal life may also contribute to the development of hypoglycemia and the increased energy requirements.

\section{REFERENCES}

1. Cassidy G, Strange M 1987 The small-for-gestational-age infant. In: Avery GB (Ed) Neonatology: Pathophysiology and Management of the Newborn. JB Lippincott Co, Philadelphia, pp 299-331

2. Gruenwald P 1966 Growth of the human fetus II. Abnormal growth in twins and infants of mothers with diabetes, hypertension, or isoimmunization. Am J Obstet Gynecol 94:1120-1203

3. Lubchenco LO, Bard H 1971 Incidence of hypoglycemia in newborn infants classified by birthweight and gestational age. Pediatrics 47:831-838

4. Wigglesworth JS 1964 Experimental growth retardation in the foetal rat. J Pathol Bacteriol 88:1-13

5. Nitzan M, Orloff S, Schulman JD 1979 Placental transfer of analogs of glucose and amino acids in experimental growth retardation. Pediatr Res 13:100 103 
6. Ogata ES, Bussey M. Finley S 1986 Altered gas exchange, limited glucose and branched chain amino acids, and hypoinsulinemia retard fetal growth in the rat. Metabolism 35:970-977

7. Bussey M, Finley S, LaBarbera A, Ogata ES 1985 Hypoglycemia in the newborn growth-retarded rat: delayed phosphoenolpyruvate carboxykinase induction despite increased glucagon availability. Pediatr Res 19:363-367

8. Pollak A, Susa JB, Stonestreet BS, Schwartz R, Oh W 1979 Phosphoenolpyruvate carboxykinase in experimental intrauterine growth retardation in rats. Pediatr Res 13:175-177

9. Nitzan M, Groffman H 1971 Glucose metabolism in experimental intrauterine growth retardation. Biol Neonate 17:420-426

10. Ogata ES. Bussey M, LaBarbera A, Finley S 1985 Altered growth, hypoglycemia, hypoalaninemia, and ketonemia in the young rat: postnatal consequences of intrauterine growth retardation. Pediatr Res 19:32-37

11. Shelley HJ, Neligan GA 1966 Neonatal hypoglycaemia. Br Med Bull 22:3439

12. Haymond MW, Karl IE, Pagliara AS 1974 Increased gluconeogenic substrates in the small for gestational age infant. N Engl J Med 291:322-328

13. Sinclair JC, Silverman WA 1966 Intrauterine growth in active tissue mass of the human fetus, with particular reference to the undergrown baby. Pediatrics 38:48-62

14. Chessex P, Reichman B, Verellen G, Putet G, Smith JM, Heim T, Swyer PR 1984 Metabolic consequences of intrauterine growth retardation in very low birthweight infants. Pediatr Res 18:709-713

15. de Leeuw R, de Vries 1976 Hypoglycemia in small-for-dates newborn infants. Pediatrics 58:18-22

16. Salle B, Ruitton-Uglienco A 1976 Glucose disappearance rate, insulin response and growth hormone response in the small-for-gestational age and premature infants of very low birth weight. Biol Neonate 29:1-17

17. Sokoloff L, Reivich M, Kennedy C, Des Rosiers MH, Patlak CS, Pettigrew KD, Sakurada O, Shinohara M 1977 The $\left[{ }^{14} \mathrm{C}\right]$ deoxyglucose method for the measurement of local cerebral glucose utilization: theory, procedure, and normal values in the conscious anesthetized albino rat. J Neurochem 28:897916

18. Leturque A, Hauguel S, Kande J, Girard J 1987 Glucose utilization by the placenta of anesthetized rats: effects of insulin, glucose, and ketone bodies. Pediatr Res 22:483-487

19. Leturque A, Revelli J-P. Hauguel S, Kande J, Girard J 1987 Hyperglycemia and hyperinsulinemia increase glucose utilization in fetal rat tissues. Am J Physiol 253:E616-E620

20. Patlak CS 1981 Derivation of equations for the steady-state reaction velocity of a substance based on the use of a second substance. J Cereb Blood Flow Metab 1:129-131

21. Ferre P, Leturque A, Burnol A-F, Penicaud L, Girard J 1985 A method to quantify glucose utilization in vivo in skeletal muscle and white adipose tissue of the anaesthetized rat. Biochem J 228:103-110

22. Girard J, Ferre P, Gilbert M, Kervran A, Assan R, Marlis EB 1977 Fetal metabolic response to maternal fasting in the rat. Am J Physiol 232:E456E462

23. Kipnis DM, Cori CV 1959 Studies of tissue permeability. V. The penetration and phosphorylation of 2-deoxyglucose in the rat diaphragm. $\mathrm{J}$ Biol Chem 234:171-177

24. Goldsmith PK, Steffen MR 1979 Different developmental changes in latency for two functions of a single membrane bound enzyme. Glucose-6-phosphatase activities as a function of age. Biochim Biophys Acta 583:133-147

25. Burchell A, Leakey JEA 1988 Development of the rat hepatic microsomal glucose-6-phosphatase system and its glucocorticoid inducibility. Biol Neonate 54:107-1 15

26. Burch HB, Kihlman AM, Skerjance J, Lowry OH 1971 Changes in patterns of enzymes of carbohydrate metabolism in the developing rat kidney. Pediatrics 47:199-206

27. Hawkins RA, Miller AL 1987 Deoxyglucose;-6-phosphate stability in vivo and the deoxyglucose method. J Neurochem 49:1941-1948

28. Domenech M, Gruppuso PA, Susa JB, Schwartz R 1985 Induction in utero of hepatic glucose-6-phosphatase by fetal hypoinsulinemia. Biol Neonate 47:92-98

29. Wertheimer E, Benneriah Y, Sasson S, Cerasi E 1989 Regulation of glucose transporter mRNA levels by glucose in muscle cells. Diabetes $38: 40 \mathrm{~A}$ (abstr)

30. Koranyi L, Bourey R, Fiedorek F, Permutt MA 1989 Alterations of brain glucose transporter mRNA in diabetic and chronic glucose starved rats Diabetes 38:65A(abstr)

31. Ogata ES, Swanson SL, Collins JW, Finley SL 1990 Intrauterine growth retardation: altered hepatic energy and redox state in the fetal rat. Pediatr Res 27:56-63

32. Bruce NW 1977 The effect on fetal development and utero-placental blood flow of ligating a uterine artery in the rat near term. Teratology 16:327-331

33. Gilbert M, Leturque A 1982 Fetal weight and its relationship to placenta blood flow and placental weight in experimental intrauterine growth retardation in the rat. J Dev Physiol 4:237-246 